\title{
Editorial
}

\section{Sustainable Environmental Solutions}

\author{
Sergio Ferro ${ }^{1, *(1)}$ and Marco Vocciante ${ }^{2(1)}$ \\ 1 Ecas4 Australia Pty Ltd., Mile End South 5031, Australia \\ 2 Department of Chemistry and Industrial Chemistry, University of Genova, 16146 Genova, Italy; \\ marco.vocciante@unige.it \\ * Correspondence: sergio@ecas4.com.au
}

check for updates

Citation: Ferro, S.; Vocciante, M. Sustainable Environmental Solutions. Appl. Sci. 2021, 11, 6868. https:// doi.org/10.3390/app11156868

Received: 14 July 2021

Accepted: 23 July 2021

Published: 26 July 2021

Publisher's Note: MDPI stays neutral with regard to jurisdictional claims in published maps and institutional affiliations.

Copyright: (c) 2021 by the authors. Licensee MDPI, Basel, Switzerland. This article is an open access article distributed under the terms and conditions of the Creative Commons Attribution (CC BY) license (https:// creativecommons.org/licenses/by/ $4.0 /)$.

\begin{abstract}
In recent decades, increasing attention has been paid to the sustainability of products and processes, including activities aimed at environmental protection, site reclamation or treatment of contaminated effluents, as well as the valorization of waste through the recovery of resources. Although implemented with 'noble intentions', these processes are often highly invasive, unsustainable and socially unacceptable, as they involve significant use of chemical products or energy. This Special Issue is aimed at collecting research activities focused on the development of new processes to replace the above-cited obsolete practices. Taking inspiration from real problems and the need to face real cases of contamination or prevent potentially harmful situations, the development and optimization of 'smart' solutions, i.e., sustainable not only from an environmental point of view but also economically, are discussed in order to encourage as much as possible their actual implementation.
\end{abstract}

Keywords: environmental pollution and remediation; hazardous waste management; circular economy; soil and water reclamation; nanomaterials; sustainable processes

\section{Introduction}

The term 'sustainability' is generally used today when discussing possible improvements to problems such as excessive exploitation of natural resources, excessive use of energy, or the release of polluting by-products during manufacturing operations. Starting from the assumption (not always assured) that ecosystems will continue to operate and maintain the conditions that make it possible not to diminish the quality of life of today's modern societies, if a process or action causes little, less or no damage to the natural world, this process or action is considered 'sustainable'. The goal of a sustainable process/action is to maintain a balance between the exploitation of resources and the improvement of the quality of life of our modern societies and to increase the current and future potential to satisfy human needs and aspirations.

This Special Issue proposes 'sustainable environmental solutions' in relation to various activities, which have been divided into the following categories: sustainable remediation, sustainable development, and sustainable production. We hope that readers will be able to find some interesting answers or an incentive to contribute to Volume 2 of this editorial work.

\section{Sustainable Remediation}

Sustainable remediation is a modality of intervention in which the effects of the implementation of environmental restoration are taken into account through actions that minimize the environmental footprint, i.e., the demands in terms of energy (through the use of renewable energy), the use of materials and the production of waste (through the reuse and recycling of materials and waste), the use of water and/or the impact on water resources, the emission of air pollutants and greenhouse gas and the use of land and the impact on ecosystems. 
The use of Luminescent Solar Concentrators (LSC) in combination with phytoremediation is an example of how energy savings can be exploited to achieve self-sufficiency of greenhouses [1].

The efficiency improvement of simple and economical processes such as solid-liquid separation (a key operation in wastewater treatment) can be promoted through the optimization of the hydrodynamic behavior of suspended particles and the rheology of sludge [2].

With regard to wastewater treatment, Pietrelli et al. [3] evaluated the potential application of chitosan, a low-cost and environmentally friendly adsorbent, in the treatment of compounds with highly toxic and carcinogenic effects on biological systems such as chromium ions, while Kim and Han [4] investigated on the use of hydrogen nanobubbles to improve the electrokinetic remediation of copper-contaminated soils. Heidarrezaei et al. [5] managed to isolate and characterize a new bacterium (Lysinibacillus boronitolerans) capable of breaking down trichloroacetic acid, a member of the class of halogenated organic compounds widely used as solvents, herbicides and pesticides, but unfortunately carcinogenic to humans and animals, and Kulikova et al. [6] proposed a cost-effective approach to the synthesis of a magnesium potassium phosphate matrix, which is promising for the solidification of radioactive waste on an industrial scale.

On the other hand, a sustainable approach to remediation can also start from the sustainable detection of the contaminants to be addressed. An example of this is the development of a cork-modified carbon paste electrode for the determination of $\mathrm{Pb}$ (II), which has proved to be a sensitive electrochemical sensor capable of meeting stringent environmental control requirements while being economical, simple and highly selective [7]. In some cases, it may also be useful to conduct an economic evaluation of the intervention through the contingent evaluation $(\mathrm{CV})$ to verify if the reduction is also socially advantageous or if the willingness to pay (WTP) for the reduction is greater than the costs involved in the reduction [8].

\section{Sustainable Development}

Speaking of sustainable development means referring to practices that make it possible to satisfy the needs of the present without compromising the ability of future generations to satisfy theirs. It means thinking about the future by balancing environmental, social and economic considerations to pursue a better quality of life. The logical or necessary consequences for society, culture, economy and the environment are interconnected and must be considered as such.

In the line of pursuing better energy efficiency in human activities, which would result in more sustainable use of resources, techniques aimed at improving the energy performances of buildings are of paramount importance, with the construction sector responsible for almost $40 \%$ of both energy consumption and the release of pollutants into the atmosphere. Among these, green roofs are becoming increasingly popular due to their ability to reduce the (electrical) energy requirements for the (summer) climatization of buildings, thus also positively influencing the internal comfort levels for the occupants [9]. The transition towards a low-carbon path should also involve agritourism buildings through the issuing of community directives, laws in member states and technical rules, including evaluation tools to assess the environmental improvements resulting from energy efficiency interventions in buildings [10].

The main obstacles to sustainable consumption are the lack of adequate infrastructure and a lack of knowledge. Infrastructure barriers in some situations make sustainable consumer behavior impossible or inconvenient (who therefore prefer other types of consumption), or in some cases require additional expenditure of time and money, thus leading to a reduction in the practice of sustainable consumer behavior [11].

To achieve the goal of ecological sustainability, influencing factors that could reduce ecological consumption need to be explored, to provide guidance for evidence-based policymaking on reducing ecological consumption [12]. 
Finally, the concept of virtual water, as a new approach to addressing water shortage and safety issues, can help support sustainable development in water-scarce regions [13].

\section{Sustainable Production}

The production of products is always linked to the extraction and consumption of natural raw materials and the use of the land. During the production process, pollutants are released into the soil, air and water and along the entire supply chain. The goal of sustainable production is to guarantee the conservation of resources and the ability of the environment to regenerate; this can be achieved by relying on processes and systems that are: non-polluting; able to limit the consumption of energy and natural resources; economically sustainable; safe and healthy for workers, communities and consumers and socially and creatively rewarding for all workers.

The growing pressure to comply with legislation and to adopt environmental strategies due to environmental concerns has led to the development of new sustainable supply chains, where a new area for a production and reconditioning system has emerged. In this complex scenario, optimal decisions can no longer avoid simultaneously considering strategies on carbon emissions, carbon tax and compulsory emissions [14].

This also applies to the food industry, with the constant search for sustainable strategies to maximize the effectiveness of the approaches and minimize the number of processes required for the production of safe food [15], the amount of drinking water required [16] and the chemicals involved, which must be as environmentally friendly and cost-effective as possible [17].

To minimize the environmental impact of industrial production, the treatment of waste linked to production is decisive, which at least in the past has always suffered from scarce attention as it is perceived as not aimed at generating value and therefore profit. In this regard, it is also appropriate to evaluate investment projects for waste treatment and try to understand their impact on the development of environmental policies [18].

\section{Future Advances in Sustainable Environmental Solutions}

It is widely believed that reconciling economic and environmental interests is not possible because they are conflicting interests. Many wonder whether it is actually possible to meet people's needs for food, water and energy by doing more to protect nature. We think the answer is yes, but we need a path to get there, and we need to make it urgently. Changing course over the next 10 years requires global collaboration at levels likely to be comparable to those seen after the Second World War. Protecting nature and providing water, food and energy to a growing world do not necessarily need to be mutually exclusive interests; on the contrary, energy, water, air, health and ecosystem initiatives are needed that intelligently balance economic growth and resource conservation needs. Achieving a sustainable future will depend on our ability to ensure both thriving human communities and abundant and healthy natural ecosystems.

We look forward to reporting on further advances in Volume 2 of the Special Issue 'Sustainable Environmental Solutions', which will soon be available to receive contributions from authors from around the world.

Funding: This research received no external funding.

Conflicts of Interest: The authors declare no conflict of interest.

\section{References}

1. Pedron, F.; Grifoni, M.; Barbafieri, M.; Petruzzelli, G.; Franchi, E.; Samà, C.; Gila, L.; Zanardi, S.; Palmery, S.; Proto, A.; et al. New light on phytoremediation: The use of luminescent solar concentrators. Appl. Sci. 2021, 11, 1923. [CrossRef]

2. Trofa, M.; D'Avino, G. Sedimentation of fractal aggregates in shear-thinning fluids. Appl. Sci. 2020, 10, 3267. [CrossRef]

3. Pietrelli, L.; Francolini, I.; Piozzi, A.; Sighicelli, M.; Silvestro, I.; Vocciante, M. Chromium(III) removal from wastewater by chitosan flakes. Appl. Sci. 2020, 10, 1925. [CrossRef]

4. Kim, D.; Han, J. Remediation of copper contaminated soils using water containing hydrogen nanobubbles. Appl. Sci. 2020, 10, 2185. [CrossRef] 
5. Heidarrezaei, M.; Shokravi, H.; Huyop, F.; Rahimian Koloor, S.; Petrů, M. Isolation and characterization of a novel bacterium from the marine environment for trichloroacetic acid bioremediation. Appl. Sci. 2020, 10, 4593. [CrossRef]

6. Kulikova, S.; Vinokurov, S.; Khamizov, R.; Vlasovskikh, N.; Belova, K.; Dzhenloda, R.; Konov, M.; Myasoedov, B. The use of MgO obtained from serpentinite in the synthesis of a magnesium potassium phosphate matrix for radioactive waste immobilization. Appl. Sci. 2021, 11, 220. [CrossRef]

7. Silva, I.; de Araújo, D.; Vocciante, M.; Ferro, S.; Martínez-Huitle, C.; Dos Santos, E. Electrochemical determination of lead using a composite sensor obtained from low-cost green materials: Graphite/cork. Appl. Sci. 2021, 11, 2355. [CrossRef]

8. Jin, S.; Kwon, Y.; Yoo, S. Economic valuation of reducing submerged marine debris in South Korea. Appl. Sci. 2020, 10, 6086. [CrossRef]

9. Cirrincione, L.; La Gennusa, M.; Peri, G.; Rizzo, G.; Scaccianoce, G.; Sorrentino, G.; Aprile, S. Green roofs as effective tools for improving the indoor comfort levels of buildings-An application to a case study in Sicily. Appl. Sci. 2020, 10, 893. [CrossRef]

10. Cirrincione, L.; La Gennusa, M.; Peri, G.; Rizzo, G.; Scaccianoce, G. Towards nearly zero energy and environmentally sustainable agritourisms: The effectiveness of the application of the European ecolabel brand. Appl. Sci. 2020, 10, 5741. [CrossRef]

11. Ratner, S.; Lazanyuk, I.; Revinova, S.; Gomonov, K. Barriers of consumer behavior for the development of the circular economy: Empirical evidence from Russia. Appl. Sci. 2021, 11, 46. [CrossRef]

12. Zhang, S.; Zhu, D.; Zhang, J.; Li, L. Which influencing factors could reduce ecological consumption? Evidence from 90 countries for the time period 1996-2015. Appl. Sci. 2020, 10, 678. [CrossRef]

13. Wang, W.; Adamowski, J.; Liu, C.; Liu, Y.; Zhang, Y.; Wang, X.; Su, H.; Cao, J. The impact of virtual water on sustainable development in Gansu province. Appl. Sci. 2020, 10, 586. [CrossRef]

14. Turki, S.; Sahraoui, S.; Sauvey, C.; Sauer, N. Optimal manufacturing-reconditioning decisions in a reverse logistic system under periodic mandatory carbon regulation. Appl. Sci. 2020, 10, 3534. [CrossRef]

15. Tenzin, S.; Ferro, S.; Khan, S.; Deo, P.; Trott, D. Spray and aerosolised pH-neutral electrochemically activated solution reduces Salmonella Enteritidis and total bacterial load on egg surface. Appl. Sci. 2021, 11, 732. [CrossRef]

16. Gámiz, J.; Grau, A.; Martínez, H.; Bolea, Y. Automated chlorine dosage in a simulated drinking water treatment plant: A real case study. Appl. Sci. 2020, 10, 4035. [CrossRef]

17. Tenzin, S.; Ogunniyi, A.; Ferro, S.; Deo, P.; Trott, D. Effects of an eco-friendly sanitizing wash on spinach leaf bacterial community structure and diversity. Appl. Sci. 2020, 10, 2986. [CrossRef]

18. Shvetsova, O.; Lee, J. Minimizing the environmental impact of industrial production: Evidence from South Korean waste treatment investment projects. Appl. Sci. 2020, 10, 3489. [CrossRef] 